\title{
CHRONIC KIDNEY AND LIVER DISEASE; ASSESSMENT OF PRESCRIBERS' KNOWLEDGE REGARDING ANTIBIOTIC PRESCRIPTION
}

1. Associate Professor Pharmacology Department, Rehman Medical College, Peshawar.

2. Assistant Professor Pharmacology Department, Punjab Medical College, Faisalabad

3. Syed Ali Sibtain Deputy Drug Controller Allied Hospital Faisalabad.

Correspondence Address: Dr. Rizwan Faisal

Associate professor, Pharmacology Department,

Rehman Medical College, Peshawar. drrizwanfaisal@hotmail.com

Article received on:

09/01/2017

Accepted for publication:

$03 / 04 / 2017$

Received after proof reading: 06/05/2017

\section{Dr. Rizwan Faisal ${ }^{1}$, Dr. Attia Anwar ${ }^{2}$, Syed Ali Sibtain ${ }^{3}$}

\begin{abstract}
Objective: To evaluate the knowledge of prescriber's regarding antibiotics prescription in patients with chronic kidney and liver disease. Study design and technique: Cross-sectional study, convenient sampling. Setting: District Faisalabad of province Punjab, Pakistan. Period: 11 months. Material \& Methods: Total 250 prescribers were approached, among which 210 prescribers responded and filled the questionnaire. Data after collection was divided into two categories: (i) on the basis of area of practice of the prescribers (urban \& rural) and (ii) on the basis of qualification of the prescribers (consultants, postgraduate residents, general practitioners \& paramedics). Results: The results of the current study revealed that knowledge of the prescribers of urban area was better as compare to the prescribers of rural area with significant difference of 0.001 . Similarly a significant difference of 0.001 was found between the knowledge of consultants, postgraduate medical residents, general practitioners and paramedics. Consultants were found to be the most knowledgeable prescribers while paramedics were the least. Conclusion: Prescribers who were practicing in urban areas and the ones who were more qualified (consultants) have sound knowledge of prescribing antibiotics in patients of chronic kidney and liver disease.
\end{abstract}

Keywords: $\quad$ Antibiotic, Chronic kidney disease, Chronic hepatic disease, Glomerular filtration rate, Bioavailibility

Article Citation: Faisal R, Anwar A, Sibtain SA. Chronic kidney and liver disease; assessment of prescribers' knowledge regarding antibiotic prescription. Professional Med J 2017;24(5):781-786. DOI: 10.17957/TPMJ/17.3874

\section{INTRODUCTION}

\section{Novelty}

Irrational use of antibiotics is really alarming in developing countries. In Pakistan 3.5 is the average no of drug per prescription in which $76 \%$ are antibiotics. In patients with CKD and CLD, the reduction in dose is required for those antibiotics which are eliminated in active form through kidneys or metabolized by liver. Mostly drugs primarily involve hepatobiliary and renal system for their metabolism and elimination respectively, hence, in order to decide drug dosing in patients of CKD and CLD, three important factors need to be considered (i) pharmacokinetic alterations of drugs, (ii) pharmacodynamic alteration of drugs, and (iii) increased susceptibility of patients to adverse events particularly nephrotoxicity and hepatotoxicity.

For this reason purpose of this study was to evaluate prescribers' knowledge regarding the antibiotic usage in patients of CKD and CLD. So far, in this regard very limited studies are conducted in Pakistan. The results of the study will suggest proper training programmes in order to improve the knowledge of the prescribers if they were found lacking the sufficient knowledge. Chronic kidney disease (CKD) is defined as abnormalities in kidney structure or function that have been present for $\geq 3$ months with or without decreasing glomerular filtration rate (GFR). ${ }^{1}$ According to the guidelines of National Kidney Foundation, it may be defined as GFR $<60 \mathrm{ml} /$ $\min / 1.73 \mathrm{~m}^{2}$ for $\geq 3$ months with or without kidney damage. ${ }^{2}$ The incidence of CKD is increasing quickly. It has been reported that there is one medication-related problem for every 2.7 dialysis patients. ${ }^{1}$ Chronic liver disease (CLD) is defined as progressive destruction of the liver parenchyma over a period greater than 6 months leading ultimately to fibrosis and cirrhosis. ${ }^{3}$ Antibiotics are considered as a common cause of drug-induced 
liver injury. Population-based estimates suggest that it occurs in $<5$ per 100000 population. ${ }^{4}$

Antibiotics are natural or synthetic substances that are used to treat or prevent bacterial infections. They produce their beneficial effect by either killing bacteria or preventing them from reproducing and spreading. Ideally, antibiotics should be prescribed only when some bacterial infections; (i) are unlikely to resolve without antibiotics (ii) could infect others unless treated, (iii) could take too long to clear without treatment (iv) carry a risk of more serious complications. ${ }^{5}$

While prescribing antibiotics factors related to the patient include history of allergy, renal and hepatic function, susceptibility to infection (i.e. whether immune-compromised), severity of illness, weight, ethnic origin, age, ability to tolerate drugs by mouth, whether taking other medication and, if female, whether pregnant, breast-feeding or taking an oral contraceptive. ${ }^{6}$ Prescribing will be rational if the antibiotics are prescribed according to the above mentioned criteria. It will be irrational if the decision is based on insufficient or improper knowledge. Therefore, not only the general information of the prescriber regarding the drug and treatment guidelines but also patient specific information such as other drugs used by the individual, drug allergies and other diseases, is also important.

Irrational use of antibiotics is really alarming in developing countries. In Pakistan 3.5 is the average no of drug per prescription in which $76 \%$ are antibiotics. ${ }^{7}$ In patients with CKD and CLD, the reduction in dose is required for those antibiotics which are eliminated in active form through kidneys or metabolized by liver. ${ }^{8}$ Mostly drugs primarily involve hepatobiliary and renal system for their metabolism and elimination respectively, hence, in order to decide drug dosing in patients of CKD and CLD, three important factors need to be considered (i) pharmacokinetic alterations of drugs, (ii) pharmacodynamic alteration of drugs, and (iii) increased susceptibility of patients to adverse events particularly nephrotoxicity and hepatotoxicity. ${ }^{9}$
For this reason purpose of this study was to evaluate prescribers' knowledge regarding the antibiotic usage in patients of CKD and CLD. So far, in this regard very limited studies are conducted in Pakistan. The results of the study will suggest proper training programmes in order to improve the knowledge of the prescribers if they were found lacking the sufficient knowledge.

\section{MATERIAL AND METHODS}

The study was conducted with a self-designed questionnaire in the urban and rural areas of the Faisalabad district of province Punjab, Pakistan to access the knowledge of the prescribers regarding antibiotic prescription in CKD and CLD patients. Total prescribers approached were 250, out of which 210 participants responded. Among these 210 participants; 38 were consultants (who completed their specialization), 54 were post graduate residents (who were doing their specialization), 91 were general practitioners (medical graduates) and 27 were paramedics (compounders, nurses, lady health visitors). The study was conducted from September 2014 to July 2015 after the approval by the Board of Scientific Studies, University of Sargodha, Sargodha. The participants were approached individually and requested to answer the questionnaire. The language of the questionnaire was English, and the time for answering it was approx. 30 minutes. While making the questionnaire, questions were designed in such a way that, if the answer of a particular question is Yes/No, it will be considered rational or irrational depending on the type of the question (Figure $1 \& 2$ ). Data after collection was divided into two categories:

- Category 1: Based on the area of practice i.e urban \& rural

- Category 2: Based on the qualification of the prescriber i.e consultants, post graduate residents, general practitioners and paramedics.

\section{STATISTICAL ANALYSIS}

The data was entered and analyzed by using SPSS 18. The results were presented in percentages according to the answers of the prescribers (Yes, No and Don't Know). Chi-square analysis was used to see the difference between the knowledge 
of urban and rural prescribers. ANOVA was applied to see any statistical difference between the knowledge of consultants, post graduate

QUESTIONNAIRE REGARDING CHRONIC KIDNEY DISEASE TO BE ASKED FROM PRESCRIBERS

\begin{tabular}{|c|c|c|c|c|}
\hline \multicolumn{5}{|c|}{ 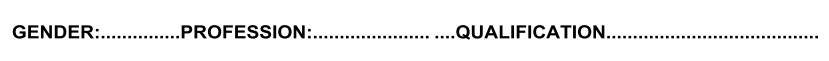 } \\
\hline \multicolumn{5}{|c|}{ 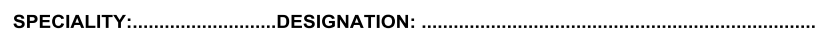 } \\
\hline \multirow{2}{*}{\multicolumn{5}{|c|}{ INSTITUTION: }} \\
\hline & & & & \\
\hline SR.No & QUESTION & YES & NO & $\begin{array}{l}\text { DON'T } \\
\text { KNOW }\end{array}$ \\
\hline \multicolumn{5}{|c|}{$\begin{array}{l}\text { Antibiotic prescribing/use will be rational if the answer is "Yes" for the following } \\
\text { questions }\end{array}$} \\
\hline & $\begin{array}{l}\text { Do you agree with the opinion that in chronic kidney } \\
\text { disease every antibiotic is not safe? }\end{array}$ & & & \\
\hline & $\begin{array}{l}\text { Do you agree that culture and sensitivity report must } \\
\text { be done before using antibiotics in patients of } \\
\text { chronic kidney disease? }\end{array}$ & & & \\
\hline & $\begin{array}{l}\text { According to your opinion, in chronic kidney disease } \\
\text { use of antibiotics having wide therapeutic index } \\
\text { should be encouraged. }\end{array}$ & & & \\
\hline & $\begin{array}{l}\text { Do you agree that the dose of an antibiotic should } \\
\text { be decreased in patients of chronic kidney disease? }\end{array}$ & & & \\
\hline & $\begin{array}{l}\text { Do you agree that monitoring the levels of antibiotics } \\
\text { can be helpful to use antibiotics prudently in patients } \\
\text { of chronic kidney disease? }\end{array}$ & & & \\
\hline & $\begin{array}{l}\text { Do you think that anuria is an important } \\
\text { consideration while prescribing antibiotic in chronic } \\
\text { kidney disease? }\end{array}$ & & & \\
\hline \multicolumn{5}{|c|}{ Antibiotic prescribing/use will be rational if the answer is "No" for the following question } \\
\hline & $\begin{array}{l}\text { Do you think that in chronic kidney disease } \\
\text { sulfonamides are the safest drugs to treat UTI? }\end{array}$ & & & \\
\hline & $\begin{array}{l}\text { Do you agree with the opinion that aminoglycosides } \\
\text { are the drug of choice in chronic kidney disease? }\end{array}$ & & & \\
\hline & $\begin{array}{l}\text { Do you use antibiotics in elderly patients without } \\
\text { testing their creatinine clearance? }\end{array}$ & & & \\
\hline
\end{tabular}

Figure-1. Questionnaire of chronic kidney disease

\section{RESULTS}

The details of the prescribers' responses based on the area of practice (urban \& rural) are shown in table $1 \& 3$ while their responses on the basis of qualification are given in table $2 \& 4$ respectively. The knowledge of the prescribers of urban area was found better as compare to the prescribers of rural area with significant difference of 0.001 . Similarly a significant difference was found between the knowledge of consultants, post graduate medical residents, general practitioners and paramedics. When further comparison was made it was found that knowledge of consultants were significantly better than postgraduate medical residents, general practitioners and paramedics with $p$-value 0.001 each. Similarly knowledge of post graduate medical residents was statistically significant from general practitioners and paramedics with $p$-value 0.001 each while general practitioners were found to be good in knowledge from paramedics with p-value 0.001 . residents, general practitioners and paramedics while Tukey's test was used for post hoc analysis. $\mathrm{P} \leq 0.05$ was considered statistically significant.

\section{QUESTIONNAIRE REGARDING CHRONIC LIVER DISEASE TO BE ASKED FROM} PRESCRIBERS

\begin{tabular}{|c|c|c|c|c|}
\hline \multicolumn{5}{|c|}{ 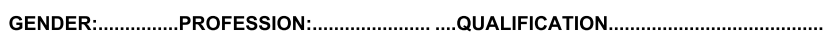 } \\
\hline \multicolumn{5}{|c|}{ SPECIALITY: } \\
\hline \multicolumn{5}{|c|}{ 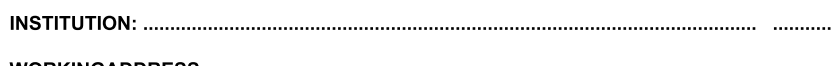 } \\
\hline \multirow{2}{*}{\multicolumn{5}{|c|}{ 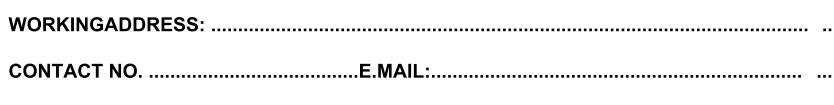 }} \\
\hline & & & & \\
\hline SR.No. & QUESTION & YES & NO & $\begin{array}{l}\text { DON'T } \\
\text { KNOW }\end{array}$ \\
\hline \multicolumn{5}{|c|}{$\begin{array}{l}\text { Antibiotic prescribing/use will be rational if the answer is "Yes" for the following } \\
\text { questions }\end{array}$} \\
\hline & $\begin{array}{l}\text { Do you agree with the opinion that in chronic liver } \\
\text { disease every antibiotic is not safe? }\end{array}$ & & & \\
\hline 2. & $\begin{array}{l}\text { Do you agree that culture and sensitivity report must be } \\
\text { done before using antibiotics in patients of chronic liver } \\
\text { disease? }\end{array}$ & & & \\
\hline 3. & $\begin{array}{l}\text { According to your opinion, in chronic liver disease use of } \\
\text { antibiotics having wide therapeutic index should be } \\
\text { encouraged. }\end{array}$ & & & \\
\hline 4. & $\begin{array}{l}\text { Do you agree that the dose of an antibiotic should be } \\
\text { adjusted in patients of chronic liver disease? }\end{array}$ & & & \\
\hline 5. & $\begin{array}{l}\text { Do you agree that monitoring the levels of antibiotics can } \\
\text { be helpful to use antibiotics prudently in patients of } \\
\text { chronic liver disease? }\end{array}$ & & & \\
\hline 6. & $\begin{array}{l}\text { Do you think that increased bi lirubin level is an important } \\
\text { consideration while prescribing antibiotics in chronic liver } \\
\text { disease? }\end{array}$ & & & \\
\hline \multicolumn{5}{|c|}{$\begin{array}{l}\text { Antibiotic prescribing/use will be rational if the answer is "No" for the following } \\
\text { questions }\end{array}$} \\
\hline 7. & $\begin{array}{l}\text { Do you agree with the opinion that Beta-lactam } \\
\text { antibiotics are the drugs of choice in chronic liver } \\
\text { disease? }\end{array}$ & & & \\
\hline 8. & $\begin{array}{l}\text { Do you agree that tetracycline is safe in chronic liver } \\
\text { disease? }\end{array}$ & & & \\
\hline 9. & $\begin{array}{l}\text { Do you use antibiotics in elderly patients without testing } \\
\text { their bilirubin level? }\end{array}$ & & & \\
\hline
\end{tabular}
Figure-2. Questionnaire of chronic liver disease

\section{DISCUSSION}

The appropriate prescribing of antibiotics and other drugs in CKD and CLD depends on knowledge of the prescribers and patient's renal and hepatic functions as they are mainly associated with the clearance and metabolism of drugs. It becomes more important in cases of certain drugs whose therapeutic window is narrow. Doses of these drugs need careful adjustment if they are prescribed for patients with impaired renal and hepatic functions. Some antibiotics also have the potential to cause renal and hepatic toxicity even in patients with normal renal and hepatic functions. Therefore, the prescriber must have sufficient and proper knowledge. A very limited data is available in this regard worldwide and especially in developing countries including Pakistan. The current study suggested that knowledge of the prescribers of urban area was better as compare to the prescribers of rural area with significant difference of 0.001 . 


\begin{tabular}{|c|c|c|c|c|c|c|c|}
\hline \multirow{2}{*}{ Question No. } & \multicolumn{3}{|c|}{ PRESCRIBERS OF URBAN AREA } & \multicolumn{3}{c|}{ PRESCRIBERS OF RURAL AREA } \\
\hline & YES & NO & DON'T KNOW & YES & NO & DON'T KNOW \\
\hline $\mathbf{1}$ & 136 & 0 & 0 & 69 & 0 & 5 \\
\hline $\mathbf{2}$ & 98 & 13 & 0 & 66 & 30 & 2 \\
\hline $\mathbf{3}$ & 103 & 6 & 4 & 72 & 14 & 10 \\
\hline $\mathbf{4}$ & 101 & 7 & 6 & 65 & 19 & 12 \\
\hline $\mathbf{5}$ & 95 & 12 & 9 & 66 & 14 & 14 \\
\hline $\mathbf{6}$ & 137 & 1 & 0 & 70 & 2 & 0 \\
\hline $\mathbf{7}$ & 5 & 107 & 4 & 10 & 75 & 9 \\
\hline $\mathbf{8}$ & 0 & 110 & 2 & 1 & 90 & 7 \\
\hline $\mathbf{9}$ & 93 & 11 & 3 & 75 & 21 & 7 \\
\hline
\end{tabular}

Table-I. Responses of urban and rural prescribers to the questionnaire of chronic kidney disease

\begin{tabular}{|c|c|c|c|c|c|c|c|c|c|c|c|c|}
\hline \multicolumn{13}{|c|}{$\begin{array}{l}\text { Prescribers approached }=250, \text { Prescribers responded }=210, \text { Consultants }=38 \\
\text { Postgraduate residents }=54, \text { General practitioners }=91, \text { Paramedics }=27\end{array}$} \\
\hline \multirow{2}{*}{$\begin{array}{l}\text { Question } \\
\text { No. }\end{array}$} & \multicolumn{3}{|c|}{ Consultants } & \multicolumn{3}{|c|}{$\begin{array}{l}\text { Post Graduate } \\
\text { Residents }\end{array}$} & \multicolumn{3}{|c|}{ General Practitioners } & \multicolumn{3}{|c|}{ Paramedics } \\
\hline & YES & NO & $\begin{array}{l}\text { DON'T } \\
\text { KNOW }\end{array}$ & YES & NO & $\begin{array}{l}\text { DON'T } \\
\text { KNOW }\end{array}$ & YES & NO & $\begin{array}{l}\text { DON'T } \\
\text { KNOW }\end{array}$ & YES & NO & $\begin{array}{l}\text { DON'T } \\
\text { KNOW }\end{array}$ \\
\hline 1 & 38 & 0 & 0 & 54 & 0 & 0 & 91 & 0 & 0 & 22 & 0 & 5 \\
\hline 2 & 30 & 8 & 0 & 46 & 8 & 0 & 72 & 19 & 0 & 17 & 8 & 2 \\
\hline 3 & 37 & 1 & 0 & 49 & 4 & 1 & 72 & 11 & 8 & 18 & 4 & 5 \\
\hline 4 & 38 & 0 & 0 & 52 & 2 & 0 & 67 & 13 & 11 & 9 & 11 & 7 \\
\hline 5 & 38 & 0 & 0 & 43 & 11 & 0 & 74 & 7 & 10 & 6 & 8 & 13 \\
\hline 6 & 38 & 0 & 0 & 54 & 0 & 0 & 90 & 1 & 0 & 25 & 2 & 0 \\
\hline 7 & 0 & 38 & 0 & 4 & 48 & 2 & 8 & 82 & 1 & 4 & 13 & 10 \\
\hline 8 & 0 & 38 & 0 & 0 & 54 & 0 & 0 & 91 & 0 & 1 & 17 & 9 \\
\hline 9 & 32 & 6 & 0 & 54 & 0 & 0 & 77 & 14 & 0 & 5 & 12 & 10 \\
\hline
\end{tabular}

Table-II. Responses of the prescribers to the questionnaire of chronic kidney disease on the basis of qualification

\begin{tabular}{|c|c|c|c|c|c|c|c|}
\hline \multirow{2}{*}{ Question No. } & \multicolumn{3}{|c|}{ PRESCRIBERS OF URBAN AREA } & \multicolumn{3}{c|}{ PRESCRIBERS OF RURAL AREA } \\
\hline & YES & NO & DON'T KNOW & YES & NO & DON'T KNOW \\
\hline $\mathbf{1}$ & 130 & 0 & 1 & 76 & 0 & 3 \\
\hline $\mathbf{2}$ & 78 & 27 & 1 & 44 & 59 & 3 \\
\hline $\mathbf{3}$ & 106 & 57 & 18 & 86 & 32 & 8 \\
\hline $\mathbf{4}$ & 122 & 5 & 2 & 73 & 3 & 5 \\
\hline $\mathbf{5}$ & 107 & 2 & 6 & 81 & 2 & 12 \\
\hline $\mathbf{6}$ & 113 & 11 & 6 & 70 & 7 & 3 \\
\hline $\mathbf{7}$ & 10 & 77 & 2 & 18 & 90 & 10 \\
\hline $\mathbf{8}$ & 11 & 102 & 4 & 19 & 63 & 9 \\
\hline $\mathbf{9}$ & 13 & 98 & 1 & 30 & 63 & 5 \\
\hline
\end{tabular}

Table-III. Responses of urban and rural prescribers to the questionnaire of chronic liver disease 


\begin{tabular}{|c|c|c|c|c|c|c|c|c|c|c|c|c|}
\hline \multicolumn{13}{|c|}{$\begin{array}{l}\text { Prescribers approached }=250, \text { Prescribers responded }=210, \text { Consultants }=38 \\
\text { Postgraduate residents }=54, \text { General practitioners }=91, \text { Paramedics }=27\end{array}$} \\
\hline \multirow[b]{2}{*}{$\begin{array}{l}\text { Question } \\
\text { No. }\end{array}$} & \multicolumn{3}{|c|}{ Consultants } & \multicolumn{3}{|c|}{ Postgraduate Residents } & \multicolumn{3}{|c|}{ General Practitioners } & \multicolumn{3}{|c|}{ Paramedics } \\
\hline & YES & NO & $\begin{array}{l}\text { DON'T } \\
\text { KNOW }\end{array}$ & YES & NO & $\begin{array}{l}\text { DON'T } \\
\text { KNOW }\end{array}$ & YES & NO & $\begin{array}{l}\text { DON'T } \\
\text { KNOW }\end{array}$ & YES & NO & $\begin{array}{l}\text { DON'T } \\
\text { KNOW }\end{array}$ \\
\hline 1 & 38 & 0 & 0 & 54 & 0 & 0 & 91 & 0 & 0 & 23 & 0 & 4 \\
\hline 2 & 22 & 14 & 2 & 29 & 25 & 0 & 47 & 44 & 0 & 22 & 3 & 2 \\
\hline 3 & 36 & 0 & 2 & 34 & 20 & 0 & 43 & 34 & 14 & 7 & 12 & 8 \\
\hline 4 & 38 & 0 & 0 & 52 & 2 & 0 & 88 & 3 & 0 & 17 & 3 & 7 \\
\hline 5 & 38 & 0 & 0 & 54 & 0 & 0 & 78 & 0 & 13 & 18 & 4 & 5 \\
\hline 6 & 38 & 0 & 0 & 51 & 3 & 0 & 83 & 8 & 0 & 11 & 7 & 9 \\
\hline 7 & 2 & 35 & 1 & 5 & 46 & 3 & 4 & 70 & 17 & 11 & 6 & 10 \\
\hline 8 & 3 & 35 & 0 & 5 & 49 & 0 & 5 & 75 & 11 & 19 & 6 & 2 \\
\hline 9 & 4 & 34 & 0 & 11 & 43 & 0 & 16 & 75 & 0 & 12 & 9 & 6 \\
\hline
\end{tabular}

Table-IV. Responses of the prescribers to the questionnaire of chronic liver disease on the basis of qualification

Similarly a significant difference of 0.001 was found between the knowledge of consultants, post graduate medical residents, general practitioners and paramedics. Consultants were found to be the prescribers with maximum knowledge than postgraduate medical residents, general practitioners and paramedics.

Both CKD and CLD are common illnesses which are associated with high mortality and require proper medication to treat or stop the progression of disease. Use of certain antibiotics and other medicines in these patients may be challenging because of idiosyncratic or dose-dependent drug toxicity..$^{10}$ As CKD and CLD alter the kinetics of drugs, therefore, drug choice and drug dose adaptations play an important role. ${ }^{11}$

A study was conducted in China to evaluate the knowledge of prescribers regarding appropriate prescription of antibiotic in patients with CKD. It was found that prevalence of inappropriate prescriptions in CKD patients was $15.18 \%$, of which, $3.23 \%$ was with unreasonable dosage, $2.65 \%$ was contraindicated and $9.29 \%$ was cautiously used antibiotics. (Ping yang 2016). ${ }^{1}$ Another study was conducted in Nigeria to assess the knowledge of prescribers in CKD, which showed that majority of prescribers have not sufficient knowledge of prescribing antibiotics. ${ }^{12}$ Both in CKD and CLD patients the prescriber should have enough knowledge while prescribing antibiotics as they may alter drug absorption, distribution, bioavailability, cytochrome P450 (CYP) metabolism and hepatic and renal clearance mechanisms.

\section{CONCLUSION}

The results of the present study revealed that knowledge of the prescribers of urban areas was satisfactory and the consultants were found to have much better knowledge regarding prescription of antibiotics in patients of CKD and CLD.

Our recommendation is that governmental and non-governmental organizations should properly educate all the health care providers especially the paramedics and the ones who are practicing in rural or urban areas but not in touch with the modern medicine \& research.

\section{Limitation of the study}

As this study is based on a single district of Pakistan, therefore, more studies are also needed in different districts of the country in order to generalize the results.

\section{Copyright (C) 03 Apr, 2017.}

\section{REFERENCES}

1. Yang P, Chen N, Wang RR, Li L, Jiang SP. Inappropriateness of medication prescriptions about chronic kidney disease patients without dialysis therapy in a Chinese tertiary teaching hospital. Ther Clin Risk Manag. 2016; 12: 1517-24.

2. National kidney foundation. http://www2.kidney.org/ professionals/kdoqi/guidelines_ckd/p4_class_g1.htm (accessed 23 December 2016). 
3. Chronic liver disease-compensated. www.oxfordmedicaleducation.com/gastroenterology/chronic-liver-disease-cld-compensated/ (accessed 26 December 2016).

4. Andrade RJ, Tulkens PM. Hepatic safety of antibiotics used in primary care. J Antimicrob Chemo ther. 2011; 66(7): 1431-46.

5. Antibiotics. http://www.nhs.uk/conditions/Antibiotics-penicillins/Pages/Introduction.aspx (accessed 28 December 2016).

6. Clinical guidelines. http://webcache.googleusercontent.com/search?q=cache:S-LIOHLw3kcJ:www. meht.nhs.uk/EasysiteWeb/getresource.axd\%3FAssetID\%3D8857\%26type\%3Dfull\%26servicetype\%3DAttachment $+\& c d=10 \& \mathrm{hl}=$ en\&ct $=$ clnk \&gl=pk (accessed 1 January 2016).

7. Abidullah et al. To determine the rational use of antibiotics; A case study conducted at medical unit of Hayatabad medical complex Peshawar. IJRANSS. 2013; 1(2): 61-68.
8. Azanza R, García E, Sádaba B, Manubens A. Antibiotic use in patients with renal or hepatic failure. Enferm Infecc Microbiol Clin. 2009; 27(10): 593-9.

9. Amarapukar DN. Prescribing medications in patients with decompensated liver cirrhosis. Int $\mathrm{J}$ of Hepatol $2011 ; 67-72$.

10. Hug BL, Surber C, Bates DW. Use of hepatotoxic drugs in chronic liver disease. J Patient Saf. 2012; 8(2): 4550 .

11. Párraga PL, López MI, Bosch VP, Latorre PF, Sánchez $D O$. Drug dosage recommendations in patients with chronic liver disease. Rev Esp Enferm Dig. 2012; 104(4): 165-84.

12. Ajemigbitse AA, Omole MK, Ezike NC, Erhun WO. Assessment of the knowledge and attitudes of intern doctors to medication prescribing errors in a Nigeria tertiary hospital. J Basic Clin Pharm. 2014; 5(1): 7-14.

\section{AUTHORSHIP AND CONTRIBUTION DECLARATION}

\begin{tabular}{|c|l|l|l|}
\hline Sr. \# & Author-s Full Name & \multicolumn{1}{|c|}{ Contribution to the paper } \\
\hline 1 & Dr. Rizwan Faisal & $\begin{array}{l}\text { Literature search, Conception \& } \\
\text { design, acquisition of data, Important } \\
\text { intellectual content and final approval } \\
\text { of the version. }\end{array}$ \\
\hline 2 & Dr. Attia Anwar & $\begin{array}{l}\text { Conception \& design, acquisition of } \\
\text { data, important intellectual content } \\
\text { and final approval of the version. } \\
\text { Literature search, Analysis and } \\
\text { interpretation of data, revising } \\
\text { the data critically for important } \\
\text { intellectual content. }\end{array}$ \\
\hline
\end{tabular}

